\title{
DETERMINATION OF PROFESSIONALISM AND TRANSPARENCY AND ITS IMPLICATIONS FOR THE FINANCIAL PERFORMANCE OF ZAKAT INSTITUTIONS
}

\author{
Rifzaldi Nasri ${ }^{1}$, Nur Aeni ${ }^{2}$ and Marissa Grace Haque-Fawzi ${ }^{3}$ \\ ${ }^{1}$ Universitas Muhammadiyah Jakarta, Indonesia, rifzaldinasri@yahoo.co.id \\ ${ }^{2}$ Universitas Muhammadiyah Jakarta, Indonesia, bunda_aini27@yahoo.com \\ ${ }^{3}$ Indonesia Banking School, Indonesia, marissahaque.ui@gmail.com
}

\begin{abstract}
The objective of this study is to determine the influence of the professionalism and transparency of zakat management on financial performance, especially in the case of the Amil Zakat Institution of Daarut Tauhid Peduli Jabodetabek. The method used in the research is SEM (structural equation modeling) using AMOS, with 156 respondents. The results show that: (1) professionalism has a negative and insignificant impact on the transparency of zakat management; (2) professionalism has a positive and significant impact on financial performance; and (3) the transparency of zakat management has positive and significant impacts on financial performance. Moreover, the indicators of competence have the highest loading factors of professionalism; the indicator of information on fund management has the highest loading factors of transparency; while the indictor of measurement of economics has the highest loading factor of financial performance. To sum up, this research suggests that zakat institutions should improve their transparency and professionalism in order to improve their financial performance in the future.
\end{abstract}

Keywords: Zakat Management, Professionalism, Transparency, Financial Performance, Structural Equation Model.

JEL Classification: G34; J24; I23.

\author{
Article history: \\ Received : October 24, 2018 \\ Revised : September 17, 2019 \\ Accepted : December 23, 2019 \\ Available online : December 27, 2019
}

https://doi.org/10.21098/jimf.v5i4.1158 


\section{INTRODUCTION}

\subsection{Background}

Zakat, infaq and shadaqah comprise a management concept called zakat. Zakat activities are Islamic da'wah ones, which play an important role and function in the effort to realise the welfare of Muslims and social justice. To execute its functions, zakat activities require good management so that zakat funds are efficient and effective for Muslims. Zakat institutions are Islamic da'wah ones that uphold socioeconomic values which, if managed and developed properly and appropriately, have an important and strategic role and function for the realisation of social justice in Islam (Endahwati, 2014).

The agencies or institutions that manage zakat, infaq and shadaqoh in Indonesia consist of two groups of institutions, namely the Amil Zakat Agency (BAZ) and the Amil Zakat Institution (LAZ), in accordance with Undang-undang No 23 tahun 2011 concerning zakat management. The organiser of BAZ and LAZ is one of the eight asnaf groups who are entitled to receive zakat, namely the Al-Amilin group. According to Hadi (2005, in Septiarini, 2011), the overall cost of managing zakat should not be more than one-eighth of the amount of zakat collection. Therefore, the role of the amil zakat, as the trustee of managing zakat funds, greatly influences the decision of the muzaki to distribute their zakat to $\mathrm{BAZ}$ and LAZ. If the amil zakat performs the mandate properly, then the seven other asnaf mustahik will be distributed well, but on the contrary if the amil zakat does not carry out the mandate properly, then the other seven asnaf mustahik will not necessarily receive zakat funds in accordance with their size. Therefore, whether BAZ and LAZ are able to collect and distribute zakat, infaq and shodaqoh funds appropriately and reliably is a deciding factor in the decision of muzaki to distribute funds to them. The many amil zakat institutions in Indonesia do not guarantee that all zakat potential is absorbed. According to PIRAC's (2012) research, the less optimal potential of zakat, if viewed from the aspect of zakat management, is a result of the large number of Muzakki who lack trust in amil zakat or the existing zakat managers.

Several studies have discussed the potential of zakat in Indonesia. First, the PIRAC study shows that the potential for zakat in Indonesia has a tendency to increase every year. Based on a survey of 10 major cities in Indonesia, PIRAC showed that the average potential of zakat per muzakki reached Rp684.55 million in 2007, up from the previous Rp416 million in 2004. Second, PEBS FEUI used the muzakki approach on the Indonesian Muslim population, with the assumption that 95 percent of the muzakki who pay zakat can projected the potential of zakat collection in 2009 to reach Rp12.7 trillion (Indonesia Economic Outlook, 2010). Third, research conducted by Syarif Hidayatullah UIN Jakarta shows that national zakat potential could reach Rp19.3 trillion. Fourth, research by Firdaus et al. (2012) shows that the potential for national zakat in 2011 reached 3.4 percent of total GDP; in other words, the potential for zakat in Indonesia was estimated at Rp217 trillion. This amount includes the potential for zakat receipts from various areas, such as zakat from households, private companies, BUMNs, as well as deposits and savings. Asfarina et al. (2019, p.388) state that the actual amount of zakat collected (not including infaq) in 2017 was Rp4.19 trillion, or equal to $0.03 \%$ of GDP. This amount is closest to the potential zakat estimation that was obtained using the 
classical figh approach with a realistic scenario, which was Rp13.26 trillion $(0.11 \%$ of GDP). This could be because the Muslim community in Indonesia is more familiar with the classical fiqh approach than the contemporary one.

Table 1.

Collection of National Zakat Funds (in Rupiah) 2015 - 2018

\begin{tabular}{ccc}
\hline Year & Zakat Collection & Percentage of GDP \\
\hline 2015 & 2.36 Trillion & 0.01 \\
2016 & 3.73 Trillion & 0.02 \\
2017 & 4.19 Trillion & 0.03 \\
2018 & 8.10 Trillion & 0.05 \\
\hline
\end{tabular}

Source : Zakat Statistics, Baznas

Therefore, while the potential amount of zakat in 2011 was Rp217 trillion, or $3.40 \%$ of GDP, BAZNAS zakat statistics show that the actual amounts of zakat collected in the three-year period from 2015 to 2018 stood at only $0.01 \%, 0.02 \%$, $0.03 \%$ and $0.05 \%$ of GDP for the four respective years.

Previous research on zakat institutions has been conducted theoretically and empirically. Wahid et al. (2009) focused on the deficiencies in the distribution of funds; Bakar and Rahman (2007) distinguished between zakat and modern taxation in Malaysia; while Wahab and Rahman (2011) proposed a conceptual model of the efficiency and governance of zakat institutions. Taha et al. (2017) found that religiosity and transparency determined improvement in the performance of a zakat institution. Likewise, Yuliafitri and Khoiriyah (2016) state that the performance of zakat management is influenced by the transparency and accountability of the amil zakat institution. Based on this explanation, there is a tendency for the low performance of a zakat agency to be caused by a lack of transparency in the management of zakat. According to Mashudi (2012), if there is low transparency of zakat management by BAZ/LAZ, this affects the success of zakat empowerment (mustahik turns into muzaki).

Devi (2018) states that the professionalism of BAZ management affects its performance. This shows that in addition to transparency, poor professionalism of BAZ managers is also alleged to be a cause of the low performance of BAZ management. This is seen in the findings of Sularno (2010), who states that there are two constraints, namely internal and external ones. Internal constraints include the absence of professional management in the management of BAZNASDA (Regional BAZNAS); the absence of a definitive honorarium for management, as many board members still work in BAZNASDA only as a side job; and the absence of a representative office. External constraints include the lack of full awareness amongst muzakki to hand over their zakat to BAZNASDA, preferring to channel it directly to mustahiq; the absence of regulations, mainly in the form of regional regulations on zakat; and the still zakat levies internally in government agencies.

From the explanations in previous studies, there is a fundamental difference with this research is the measurement of the financial performance of amil zakat institutions using 3E: economy, efficiency and effectiveness (Wise, 2001), while the transparency determinant is measured by the professionalism of amil zakat. 


\subsection{Objective}

The purpose of this study is to contribute to the performance measurement of amil zakat institutions. In more detail, the objectives of the study include:

1. To prove the direct influence of professionalism on the performance of Amil Zakat Institution Daarut Tauhiid Peduli Jabodetabek.

2. To prove the influence of professionalism on the transparency of zakat management by Amil Zakat Institution Daarut Tauhiid Peduli Jabodetabek.

3. To prove the influence of zakat management transparency on the performance of Amil Zakat Institution Daarut Tauhiid Peduli Jabodetabek.

\section{LITERATURE REVIEW}

\subsection{Background Theory}

Performance is basically a multidimensional concept that cannot only be equated with certain aspects. The performance of an organisation can be assessed in the form of competence, time, quality, innovation, efficiency, effectiveness and other dimensions (Fitzgerald, Johnston, Brignall, \& Silvestro, 1991).

The performance evaluation of the Amil Zakat Institute in this study employs the 3E method. According to Wise (2001), the 3E (economy, efficiency and effectiveness) of performance is useful in evaluating nonprofit organisations. The relationship between organisational goals and the inputs used is a measure of the economy. The relationship between inputs and outputs is a measure of the efficiency of the organisation, while the relationship between outputs and organisational goals is a measure of effectiveness.

Conceptually, the measurement of 3E proposed by Wise (2001) can be explained by Figure 1.

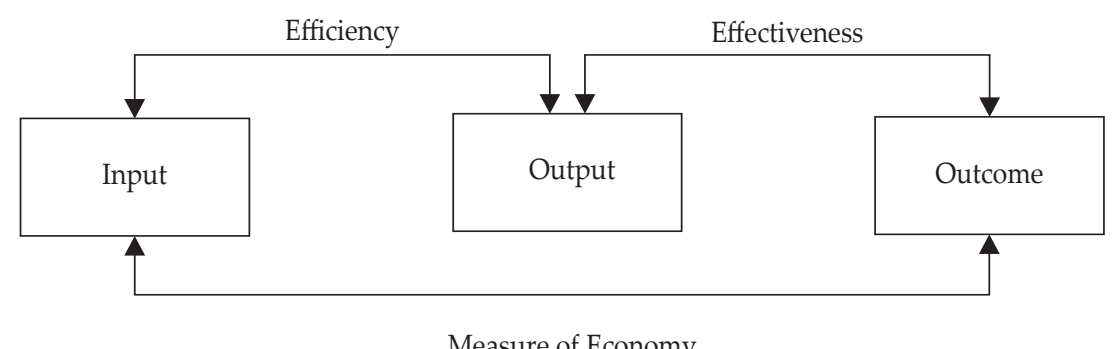

Source: Wise (2001), modified by Sulaiman (2009)

Figure 1.

Relationship between Economy, Efficiency and Effectiveness (3E)

Transparency is an element of assessment in good corporate governance (GCG), which comprises four main components (Kaen, 2003): fairness, transparency, accountability and responsibility. These four components are important because the application of the principles of good corporate governance has consistently been proven to improve the quality of financial statements, but can also be an obstacle to performance engineering activities, resulting in financial statements not reflecting the fundamental value of the company. 
Transparency (openness of information) is openness in implementing the decision-making process and openness in presenting material and relevant information about the company. It involves submitting reports to all parties openly, related to the operation of management, by including all elements as the basis for decision making and the process of implementing activities (Hasan, 2011). Building transparency in zakat management will create a good control system between the two parties, namely institutions and stakeholders, because it does not only involve internal organisations (zakat institutions), but also external parties, namely muzakki or the wider community. It should be used as a way to reduce suspicion and minimise the mistrust of the community. In the measurement of professionalism, five dimensions are used: devotion to the profession, social obligations, independence, trust in the profession, and relationships with fellow professionals (Kurniawanda, 2013: 28).

Professionalism itself consists of three dimensions, namely commitment, competence and partnership (Maister, 1997). Competence is an ability related to the knowledge and skills possessed, both from education and training, while commitment is a condition whereby people make an agreement (attachment), both to themselves and to others, which is reflected in certain actions/behaviours that are carried out voluntarily or in a forced way. There are three models of commitment to the company where people work: love for the work (affective commitment); fear of losing one's job (continuance commitment), and the sense of obligation (normative commitment). Partnership is a form of mutually beneficial cooperation between two or more parties to achieve a common goal.

\subsection{Previous Studies}

Research on zakat institutions employing measurements of efficiency, effectiveness and economic size has been conducted previously. Noor et al. (2007) requested a modeling model for OPZ. In their proposal, they use 25 variables divided into four elements, namely output, input, quality and process.

Rahman (2007) suggests three conditions for zakat to be an effective part of the financial system in Malaysia: (1) the existence of an objective and fair measurement of the amount of zakat funds for business; (2) the existence of zakat accounting practice standards; and (3) the existence of a performance measurement system.

For Zainal et al. (2016), satisfaction with zakat distribution should have a significant positive relationship with stakeholder trust in zakat institutions and service quality should have a significant positive relationship with stakeholder trust in the institutions. Akbar (2009), using DEA to measure the performance of amil zakat institutions, concluded that the efficiency of OPZ in 2005 was better than in 2006 and 2007, both technically (94.52\%), in terms of scale (75\%) and overall (71.27\%). Calculation of nine OPZ in 2007 with the assumption of CRS shows that only two OPZ were efficient, namely BMM and Bamuis BNI. The main cause of inefficiency was funds being channeled and pooled, which accounted for $43.1 \%$ and $36 \%$ respectively. The input orientation measurement showed that the source of inefficiency was another operational cost of $34.9 \%$ and a socialisation cost of 31.1\%. Using DEA, Wahyuni (2016) performed efficiency measurement of the National Zakat Management Organization with an intermediation approach, 
showing efficient performance of the National Amil Zakat Agency, Dompet Dhuafa, Lazis Nahdlatul Ulama, and the Ummat Caring Justice Post (PKPU). Measurement with a production approach showed inefficiencies in BAZNAS and Dompet Dhuafa, especially in the variable operational costs, personnel costs, ziswaf socialisation costs, and ziswaf funds channeled.

Wahab and Rahman (2011) proposed a conceptual model of the efficiency and governance of zakat institutions and identified appropriate methods to evaluate this. Such evaluations are crucial for the Islamic financial system to function effectively in order to achieve the noble objectives of socio-economic justice through proper distribution of wealth.

Bastiar and Bahri (2019), in their article entitled Model of the Measuring Performance of Zakat Institutions in Indonesia, concluded that the performance of zakat institutions can be measured using several methods, including measurement of the National Zakat Index (IZN) model; exchange using the Zakat Village Index (IDZ, the measurement model of the Center of Islamic Business and Economic Studies (CIBEST); balanced scorecard measurement; Indonesia Magnifinance of Zakat (IMZ); the International Standard of Zakat Management; or ISZM measurement models. All of these models need to be comprehensively studied together so that each concept can be aligned accordingly with the scope carried out so as to create maximum benefit from the data received from the research.

Several other studies conclude that the efficiency of donation institutions (charity) is one of the main factors that influences donors' decision making (Trussel \& Parson, 2008; Muda et al., 2006; Habib, 2008; Sari et al, (2013) said that there are two methods of zakah collection and distribution, i.e. the governmental and non-governmental approach. The government established approach consists of Badan Amil Zakah (BAZ) and Baitul Mal, while the non-governmental approach consists of Lembaga Amil Zakah (LAZ) (such as Dhuafa Wallet and Zakah Home), mosques, Islamic boarding schools (pesantren) and from individuals. Lack of coordination between all zakah management institutions has resulted in the achievement of zakah collection and distribution which is lacking. The existence of the trust to the board of the crisis the government formed between the inhibited zakah management of Indonesia. Besides the sociological aspects of weakness, the juridical aspect is also a reason why potential zakah in Indonesia has not fully achieved.

From previous studies, it appears that the performance measurement of amil zakat institutions is not optimal, as almost all studies only measure efficiency with a variety of assessment factors (Laela, 2010; Noor et al., 2007; Rahman, 2007), whereas in the concept of Wise (2001), measurements are carried out by 3E, namely efficiency, effectiveness and economy.

This research is more comprehensive than previous studies, because performance measurement fully employs the 3E concept, transparency of management as part of good corporate governance, and the professionalism of amil zakat as an individual manager of zakat. The aim is to establish whether professionalism and transparency have an influence on the financial performance of amil zakat institutions. 


\subsection{Conceptual Framework}

On the basis of previous studies, the researchers decided to examine the influence of professionalism on the transparency of zakat management and its implications for the financial performance of the Lembaga Amil Zakat Daarut Tauhiid Peduli, based on the mindset shown in Figure 2.

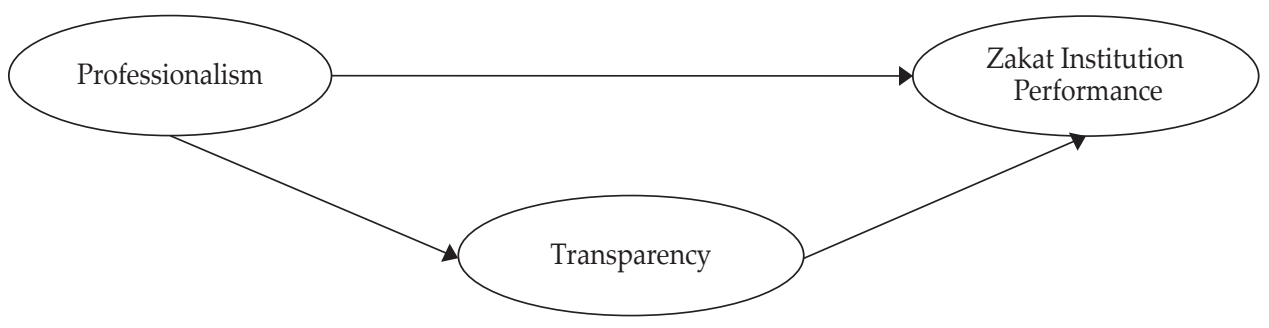

Figure 2.

Conceptual Framework

The relationship between and the influence of professionalism on the transparency of zakat management cannot be clearly explained. Revers (2014) concluded that Twitter is successful in journalism because it can ease the tension that occurs in the profession with transparency aspects. In a study that discusses the influence of professionalism on transparency, Adnan (2017) agrees that the influence of professionalism in the management of zakat by the zakat institution. Professional zakat management will encourage the zakat movement. The studies above have not explicitly analysed the intended effect. This study therefore intends to test the following hypothesis:

Hypothesis 1: Professionalism has a direct and positive influence on the transparency of zakat management in zakat institutions.

According to Firmansyah and Devi (2017), to achieve transparency zakat institutions must create financial reporting standards, followed by transparency in the distribution of zakat, and knowledge about decision making. Another study by Septiarini (2011) found that transparency, which is a manifestation of Tabligh in Islam, had a positive and significant impact on the collection of zakat, infaq and sodaqoh at LAZ Surabaya. Another study conducted by Nurhayati and Rahmi (2016) on LAZ in Bandung reinforces the results of Dina, finding that financial reporting transparency has a positive and significant effect on LAZ's zakat revenue financial performance in Bandung. On the basis of this, the second research hypothesis is:

Hypothesis 2: Transparency in the management of zakat directly influences the performance of zakat institutions.

Research conducted by Cahyasumirat (2006), which examines the effect of professionalism and organisational commitment on internal auditor performance, concludes that professionalism positively influences internal auditor job satisfaction, but does not have a positive effect on performance, while organisational commitment does not affect job performance or satisfaction. Devi (2018) concludes 
that there is a positive and significant influence on the professionalism of amil zakat on performance. This study aims to examine the effect of professionalism on the performance of amil zakat institutions, so the third hypothesis proposed is: Hypothesis 3: Professionalism has a positive effect on the performance of zakat institutions.

\section{METHODOLOGY}

\subsection{Data}

The approach used in this study is descriptive, and employs the verification research method. This method is based on an explanatory survey in order to describe the causal relationship between the variables studied.

The population in the study were 160 Amil Daarut Tauhiid institutions in Jabodetabek comprising 150 people, with the following breakdown: Pejaten 25, Cipaku 30, Tangerang Selatan 25, Bekasi 40 and Bogor 30.

The approach to determining the sample was based on the probability sampling technique, namely that each member of the population has the same rights and opportunities to be chosen as a sample (respondent). The simple random sampling technique was used; that is, the sampling was conducted randomly, without regard to the strata that exist in the population because the population is homogeneous. Other considerations in choosing the sample included lower costs, greater accuracy of results, speed of data collection, and representation of population elements.

Determining the sample size was based on representativeness and population size, and was expected to produce a better sample. Likewise, the determination of the sample in the test with the structural equation model (SEM) approach refers to Hair et al. (2006: 741), in that the number of respondents should be 5-10 times the total indicator, and to estimate the maximum likelihood method requires a minimum sample of 100 . In this study, data were obtained by distributing questionnaires to 150 people (10 times 15 indicators). There were 15 indicators: six professionalism ones; 2) four of transparency; and 3) five financial performance indicators.

The data used in the study were derived from primary data. These refer to the data of all the research variables collected directly from the research object, the Daarut Tauhiid Amil Zakat Institution in Jabodetabek, through a field survey with custom-made research instruments.

\subsection{Model Development}

Based on the conceptual framework and previous studies, the researchers considered the influence of professionalism on the transparency of zakat management and its implications for the financial performance of the Amil Zakat Daarut Tauhiid Peduli Institute, based on the model shown in Figure 3.. 


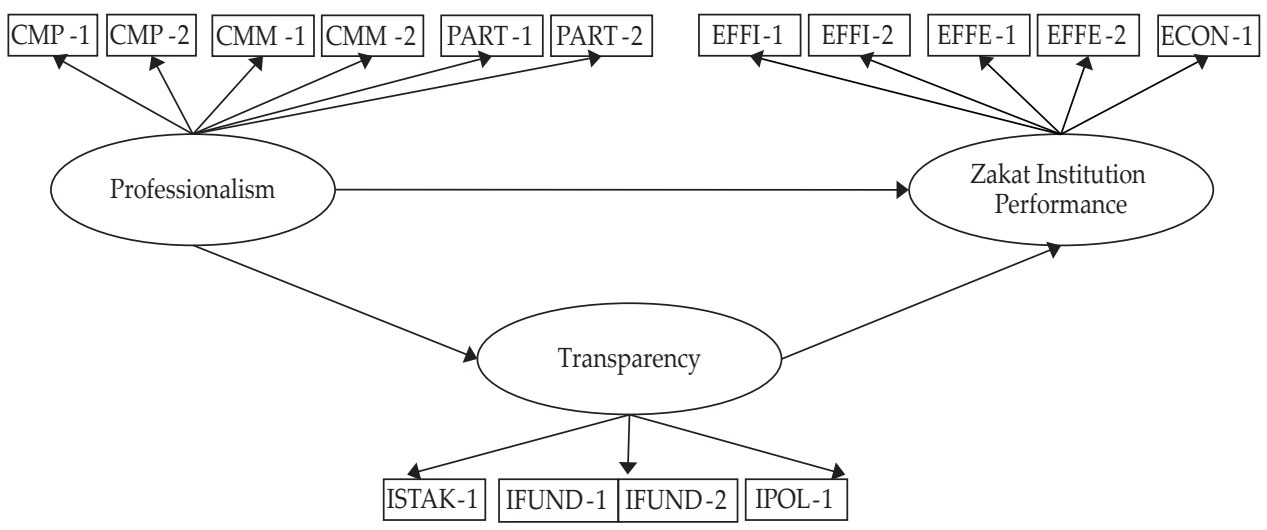

Figure 3.

Proposed Model

The first measure used to assess the financial performance of zakat institutions was efficiency, which means achieving maximum output with certain inputs, or using the lowest inputs to achieve certain outputs. Efficiency is the ratio of output to input, associated with performance standards or targets that have been set. It refers to the best ratio between output and cost (input). Because outputs and costs are measured in different units, efficiency can be realised when existing maximum resource output can be achieved, or certain outputs can be achieved with the least possible resources.

The second measure used to measure performance is effectiveness. This means the level of achievement of the program results with the targets set. It is a comparison between outcome and output. Outcome is often associated with the objectives or targets to be achieved. Therefore, it can be said that effectiveness is related to achieving goals. It aims to determine the level of achievement of the desired results or benefits.

The third measure is the measurement of economy, which compares the purpose of the formation of the amil zakat institution, namely distribution of zakat to eight asnaf (the groups entitled to receive it), with output.

The transparency variable of zakat management is measured by four indicators, the professionalism variable measured by six indicators, with five indicators of performance. Details of the dimensions and indicators for each variable can be seen in Table 2. 
Table 2.

Indicators of Latent Variables

\begin{tabular}{|c|c|c|}
\hline Dimension & Indicator & Reference \\
\hline \multicolumn{3}{|c|}{ Professionalism } \\
\hline \multirow[b]{2}{*}{ Competence } & The ability to analyse zakat objects (CMP1) & Rahman (2013) \\
\hline & $\begin{array}{l}\text { The ability to make reports on accountability in } \\
\text { accordance with modern accounting principles (CMP2) }\end{array}$ & Rahman (2013) \\
\hline \multirow[t]{2}{*}{ Commitment } & $\begin{array}{l}\text { Serving the people who pay the zakat/muzaki well } \\
\text { (CMM1) }\end{array}$ & Rahman (2013) \\
\hline & Serving the recipients of zakat/mustahik well (CMM2) & Rahman (2013) \\
\hline \multirow[b]{2}{*}{ Partner } & Having a special officer who explains zakat (PART1) & Rahman (2013) \\
\hline & $\begin{array}{l}\text { Having special officers who collaborate with zakat } \\
\text { collection organisations (PART2) }\end{array}$ & Rahman (2013) \\
\hline \multicolumn{3}{|c|}{ Transparency } \\
\hline $\begin{array}{l}\text { Information to } \\
\text { Mustahik }\end{array}$ & $\begin{array}{l}\text { Providing written information/data to the zakat givers } \\
\text { on time (ISTAK1) }\end{array}$ & Irman (2017) \\
\hline \multirow{2}{*}{$\begin{array}{l}\text { Information on } \\
\text { fund management }\end{array}$} & $\begin{array}{l}\text { Providing regular data/information to the zakat givers } \\
\text { (IFUND1) }\end{array}$ & Irman (2017) \\
\hline & $\begin{array}{l}\text { Providing data/information at the zakat agency office } \\
\text { (IFUND2) }\end{array}$ & $\operatorname{Irman}(2017)$ \\
\hline $\begin{array}{l}\text { Information on } \\
\text { zakat institution } \\
\text { policy }\end{array}$ & $\begin{array}{l}\text { Providing data/information according to the policies set } \\
\text { by the zakat institutions (IPOL1) }\end{array}$ & Irman (2017) \\
\hline \multicolumn{3}{|c|}{$\begin{array}{r}\text { Financial Performance } \\
\end{array}$} \\
\hline \multirow{2}{*}{ Efficiency } & Program cost ratio (EFFI1) & Poister (2003) \\
\hline & Operational cost ratio (EFFI2) & Poister (2003) \\
\hline \multirow{2}{*}{ Effectiveness } & Ratio of achievement of educational assistance (EFFE1) & Poister (2003) \\
\hline & Ratio of achievement of economic assistance (EFFE2) & Poister (2003) \\
\hline $\begin{array}{l}\text { Measurement of } \\
\text { Economy }\end{array}$ & Viability rights ratio (ECON1) & Poister (2003) \\
\hline
\end{tabular}

\subsection{Method}

To analyse the data in the study, the structural equatation modeling (SEM) method was used. This is also well known as the linear structural relationship (LISREL) model, or sometimes as the JKW model (Ascarya and Rahmawati, 2018). It was first developed in 1973 by Karl Jöreskog, and was combined with a model developed by Keesling (1973) and Wiley (1973).

Mulaik (1972) states that three aspects are considered in SEM, namely 1) the specific structure between exogenous and endogenous latent variables is structured, can be hypothesized; 2) it has been determined to use exogenous latent variables; and 3) the measurement models for the endogenous latent variables has been determined. Based on the following concepts, research in data analysis with SEM involves 1) validity and reliability testing (comparison with factor analysis); (2) a model relationship test between variables (path analysis); and 3) model confirmation (SEM).

Lee (2007) states that structural equation models are well recognised as the most important statistical method to serve the purposes discussed above and 
can be applied to many fields. SEM uses statistical methods to present data in achieving research objectives and can apply many models in formulating answers to the research problem.

According to Hair (1998), several steps must be taken when using SEM, including 1) development of a model that has a strong theoretical justification; 2) development of path diagrams, which make it easy for researchers to see the causality relationships to be tested; and 3) conversion of the specifications of the model into series of equations, namely a) structural equations and b) measurement models. The size components identify the latent variables and structural components in order to evaluate the hypotheses of causal relationships between the latent variables in the causal model and to show the testing of all the hypotheses in the model as one or as a whole.

\section{RESULTS AND ANALYSIS}

\subsection{Results}

Structural equation modeling is a multivariate statistical analysis technique that is used to analyse structural relationships. The technique is the combination of factor analysis and multiple regression analysis, and is used to analyse the structural relationship between measured variables and latent constructs. In this analysis, two types of variable are used: endogenous and exogenous variables. Endogenous variables are equivalent to dependent variables and are equal to the independent variable (Bentler \& Chou, 1987).

This can be thought of as a set of relationships providing consistency and comprehensive explanations of the actual phenomena. There are two types of model:

1. Measurement model: Represents the theory that specifies how the measured variables come together to represent the theory.

2. Structural model: Represents the theory that shows how constructs are related to other constructs.

\subsubsection{Measurement Model}

\section{a. Goodness Of Fit Index (GFI)}

Table 3.

RMR, GFI Test Results

\begin{tabular}{lcccc}
\hline Model & RMR & GFI & AGFI & PGFI \\
\hline Default model & 0.059 & 0.931 & 0.939 & 0.430 \\
Saturated model & 0.000 & 1.000 & & \\
Independence model & 0.080 & 0.473 & 0.397 & 0.414 \\
\hline
\end{tabular}

Source: AMOS results

In Table 3 it can be seen that the default GFI model is 0.931 , or greater than the benchmark value of $0.90(0.931 \geq 0.90)$. This shows that the model has a good fit. 


\section{b. Root Mean Square Error Of Approximation (RMSEA)}

Table 4.

RMSEA Test Results

\begin{tabular}{lcccc}
\hline Model & RMSEA & LO 90 & HI 90 & PCLOSE \\
\hline Default model & 0.027 & 0.176 & 0.258 & 0.000 \\
Independence model & 0.248 & 0.212 & 0.284 & 0.000 \\
\hline
\end{tabular}

Source : AMOS results

Table 4 shows that the default RMSEA model is 0.027 , which is lower than the benchmark value of $0.08(0.027 \leq 0.080)$. This shows that the number of samples taken can be used as a model in the study.

\section{c. Adjusted Goodness-Of-Fit (AGFI)}

Table 5.

AGFI Test Results

\begin{tabular}{lcccc}
\hline Model & RMR & GFI & AGFI & PGFI \\
\hline Default model & 0.059 & 0.931 & 0.939 & 0.430 \\
Saturated model & 0.000 & 1.000 & & \\
Independence model & 0.080 & 0.473 & 0.397 & 0.414 \\
\hline
\end{tabular}

Source : AMOS results

Table 5 shows that the default AGFI model is 0.939 , which is greater than the benchmark value of $0.90(0.939 \geq 0.90)$. This shows that the model has a good fit.

\section{d. Tucker-Lewis Index (TLI)}

Table 6.

Tucker Lewis (TLI) Test Results

\begin{tabular}{lccccc}
\hline Model & $\begin{array}{c}\text { NFI } \\
\text { Delta1 }\end{array}$ & $\begin{array}{c}\text { RFI } \\
\text { rho1 }\end{array}$ & $\begin{array}{c}\text { IFI } \\
\text { Delta2 }\end{array}$ & $\begin{array}{c}\text { TLI } \\
\text { rho2 }\end{array}$ & CFI \\
\hline Default model & 0.292 & 0.145 & 0.428 & 0.956 & 0.967 \\
Saturated model & 1.000 & & 1.000 & & 1.000 \\
Independence model & 0.000 & 0.000 & 0.000 & 0.000 & 0.000 \\
\hline Source : AMOS results & & & & &
\end{tabular}

Source : AMOS results

From Table 6, it can be seen that the default TLI model is 0.956 , or greater than the benchmark value of $0.90(0.956 \geq 0.90)$. This shows a balanced measure between model identification and model modification.

The results of the measurement model are illustrated in the use of AMOS, as shown in Table 7. 
Table 7.

Measurement Model Results

\begin{tabular}{|c|c|c|c|c|c|c|c|}
\hline & & Estimate & S.E. & C.R. & $\mathbf{P}$ & Label & Conclusion \\
\hline Transparency & <--- Professionalism & -0.185 & 1.939 & -0.632 & 0.528 & par_13 & Ho accepted \\
\hline Financial Perf & $<---$ Tranparency & 0.469 & 0.111 & 2.560 & 0.009 & par_14 & Ho rejected \\
\hline Financial Perf & <--- Professionalism & 0.465 & 1.340 & 2.844 & 0.019 & par_15 & Ho rejected \\
\hline PART 2 & $<---$ Professionalism & 0.198 & & & & & \\
\hline PART 1 & <--- Professionalism & -0.213 & 1.497 & -0.722 & 0.471 & par_1 & \\
\hline CMM 2 & <-- Professionalism & -0.032 & 1.857 & -0.156 & 0.876 & par_2 & \\
\hline CMM 1 & $<---$ Professionalism & -0.511 & 3.461 & -0.931 & 0.352 & par_3 & \\
\hline CMP 2 & $<---$ Professionalism & -0.942 & 5.495 & -0.970 & 0.332 & par_4 & \\
\hline CMP 1 & $<---$ Professionalism & -0.768 & 5.588 & -0.969 & 0.332 & par_5 & \\
\hline EFFI 2 & <--- Financial Perf & 0.437 & & & & & \\
\hline EFFI 1 & <--- Financial Perf & 0.567 & 0.393 & 2.186 & 0.029 & par_6 & \\
\hline EFFE 1 & <--- Financial Perf & -0.090 & 0.366 & -0.491 & 0.623 & par_7 & \\
\hline EFFE 2 & $<--$ Financial Perf & -0.024 & 0.444 & -0.133 & 0.894 & par_8 & \\
\hline M. ECON 1 & $<--$ Financial Perf & -0.912 & 9.799 & 2.088 & 0.037 & par_9 & \\
\hline ISTAK & <--- Tranparency & 0.810 & & & & & \\
\hline IFUND 1 & <--- Tranparency & 0.294 & 0.168 & 1.387 & 0.165 & par_10 & \\
\hline IFUND 2 & $<---$ Tranparency & 0.860 & 0.276 & 3.346 & $* * *$ & par_11 & \\
\hline IPOL & $<---$ Tranparency & 0.250 & 0.226 & 1.176 & 0.240 & par_12 & \\
\hline
\end{tabular}

Hypothesis Testing Criteria If $\mathrm{CR}<1.96$ or probability $(\mathrm{P})>0.05$, Ho is accepted. Based on Table 7 and the criteria used, professionalism has no direct influence on transparency (CR-0.632 <1.96, P $0.528>0.05)$. However, transparency has an influence on financial performance (CR 2.560> 1.96, P $0.009<0.05)$ and professionalism influences financial performance (CR 2.844> 1.96, P $0.019<0.05)$. The validity of competency dimensions (CMP2) is the dimension with the highest standardised loading factor of 0.942 in forming the professionalism variable. Therefore, the competency dimension is the dominant one in shaping the latent variable of professionalism.

Dimensional validity in the formation of the transparency latent variable on zakat management, information on fund management (IFUND2) is the dimension with the greatest validity, with a standardised loading factor value of 0.860 in forming the fund management transparency variable.

Likewise, with the dimension validity in the formation of financial performance latent variables, the measurement of economics (M.ECON1) is the dimension with the greatest validity, with a standardised loading factor value of 0.912 in forming financial performance variables. 


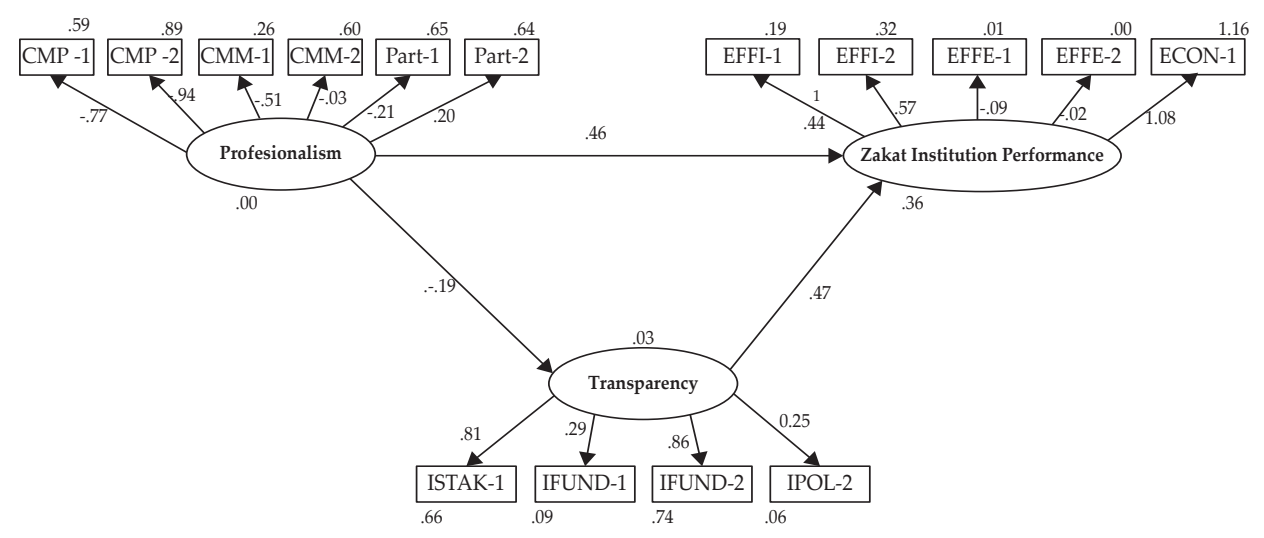

Figure 4.

Hybrid (Full SEM) Standardized Model

\subsubsection{Structural Model}

1. The first hypothesis (H1) proposes that professionalism influences the transparency of zakat management.

Based on Figure 4, it can be seen that the path coefficient of the professionalism variable on the transparency of zakat management is -0.185 , with a CR value of $-0.632<1.96$ or a probability value of $0.528>0.05$, so it can be said to be insignificant. The magnitude of the path coefficient shows that the direct contribution of the influence of professionalism on the transparency of zakat management is (-0.185) $2=0.03$. Therefore, professionalism is not proven to have a positive and significant effect on the transparency of zakat management, or in other words Hypothesis 1 (H1) is rejected.

2. The second hypothesis $(\mathrm{H} 2)$ posits that professionalism influences financial performance.

Based on Figure 4, it can be seen that the path coefficient of the professionalism variable on financial performance is 0.465 , with a CR value of $2.844>1.96$ or a probability value of $0.019<0.05$, so it can be said to be significant. The magnitude of the path coefficient shows that the extent of the direct influence of professionalism on financial performance is $(0.465) 2=0.216$, while the indirect effect of professionalism on financial performance is 0.218 , so the total effect of professionalism on financial performance is 0.434 . Consequently, professionalism is proven to have a positive and significant effect on financial performance, so Hypothesis 2 (H2) is accepted.

3. The third hypothesis (H3) states that the transparency of zakat management affects financial performance.

Based on Figure 4, it can be seen that the path coefficient magnitude of the zakat management transparency variable on financial performance is 0.469 , with a CR value of $2.560>1.96$ or a probability value of $0.009<0.05$, so it can be said to be significant. The magnitude of the path coefficient shows that the extent of the contribution of the direct influence of the transparency of zakat management on financial performance is (0.469) $2=0.219$. Therefore, the transparency of zakat management is proven to have a positive and significant effect on financial performance, meaning Hypothesis 3 (H3) is accepted. 
The results of the analysis of the testing of the variables of professionalism, transparency of zakat management and overall financial performance can be seen in Table 7 below.

Table. 7

Hypothesis Test Results

\begin{tabular}{|c|c|c|c|c|c|c|c|}
\hline & & & Estimate & S.E. & C.R. & $\mathbf{P}$ & Conclusion \\
\hline Transparency & $<$ & Professionalism & -1.224 & 1.939 & -0.632 & 0.528 & Ha Rejected \\
\hline F.Performance & $<$ & Transparency & 0.173 & 0.111 & 2.560 & 0.009 & Ha Accepted \\
\hline F.Performance & $<$ & Professionalism & 1.130 & 1.340 & 2.844 & 0.019 & Ha Accepted \\
\hline
\end{tabular}

Source: AMOS data processing results

Based on the hybrid model in figure 4 and the results of testing the hypotheses, the large direct and indirect effects of professionalism on financial performance through the transparency of zakat management are as follows:

Table 8.

Level of Direct and Indirect Effects on Financial Performance

\begin{tabular}{lccc}
\hline Effect & Direct (D) & $\begin{array}{c}\text { Indirect (I) Through Zakat } \\
\text { Management Transparency }\end{array}$ & Conclusion \\
\hline $\begin{array}{l}\text { Professionalism } \rightarrow \text { Financial } \\
\text { Performance }\end{array}$ & $(0.465) 2=0.2162$ & $(-0.185 \times 0.469)=-0.0868$ & D $>$ I \\
\hline
\end{tabular}

Source: Data processing results, 2018

The direct (D) effect of professionalism on financial performance is equal to $(0.465)^{2}=0.2162$, while the indirect (I) effect through the transparency of zakat management is $(-0.185 \times 0.469)=-0.0868$.

It can be concluded that $\mathrm{D}>\mathrm{I}$, which shows that professionalism cannot improve financial performance either directly or indirectly through the transparency of zakat management, but that thedirect influence is more dominant. Therefore, the financial performance of the Daarut Tauhiid Amil Zakat Institution in Jabodetabek will increase if its professionalism is able to increase the transparency of zakat management. This means that in the influence of professionalism on financial performance, the zakat management transparency variable is a non-mediating variable.

Based on the results of testing the hypotheses, the findings of the study are that the financial performance of the Daarut Tauhiid Amil Zakat Institution, especially in the dimension of economic measurement (ECON1), if it is able to increase the transparency of zakat management, especially in the dimensions fund management information (IFUND2), where the transparency of zakat management will increase if the Daarut Tauhiid Amil Zakat Institution in Jabodetabek Jakarta is able to increase professionalism, especially in the competency dimension (CMP1), which is supported by increasing commitment and partnership.

Based on the results of the above research findings, it appears that the main problem in this study is that financial performance remains low, especially the 
measurement of economic in terms of the distribution of fii sabilillah rights as recipients of zakat in the Daarut Tauhiid Amil Zakat Institution, Jabodetabek.

\subsection{Analysis}

The results of this study are very different from previous ones because the performance measurement fully uses 3E, whereas Laela's (2010) research only measures efficiency with different exogenous factors/variables. However, the results are in accordance with Taha et al. (2017), who found that religiosity and transparency determine improvement in the performance of a zakat institution.

Research conducted by Wahab and Rahman (2012) using DEA concludes The results also suggest that pure technical inefficiency dominates the scale inefficiency effects in determining the technical efficiency of zakat institutions in Malaysia. Further analysis of the Spearman and Pearson correlation coefficients suggests that while Muslim states with higher populations tend to positively correlate with zakat collection, the correlation with efficiency scores does not indicate a strong relationship, implying that it does not promise the efficiency of zakat organisations. In this study, the greatest value of the performance of zakat institutions relates to economic indicators.

The results of this study are consistent with those of Wahab et al. (2017). Performance evaluations are crucial for organisations such as zakat institutions to function effectively and achieve the noble objectives of socio-economic justice through proper distribution of wealth.

The calculation results show that professionalism will be better achieved if the Amil Zakat Daarut Tauhiid Institute focuses on high competency through the ability to make accountability reports in accordance with modern accounting principles. This will consequently have an impact on the transparency of zakat management, especially on the high dimensions of fund management information by providing data/information at the zakat agency office.

On the other hand, transparency in the management of zakat will be more effective if the Amil Zakat Institution Daarut Tauhiid Cares Jabodetabek is able to increase such transparency by focusing on the dimensions of fund management information by providing data/information at the zakat agency office. This will have an impact on increasing financial performance, especially in the high dimension measurement of economic in terms of the distribution of sabilillah fii rights as recipients of zakat.

\section{CONCLUSION AND RECOMMENDATION}

\subsection{Conclusion}

This section draws conclusions related to the objectives of the study, as well as describing the findings obtained.

a. Professionalism has a negative and insignificant effect on the transparency of zakat management. This shows that increasing or increasing professionalism will not be able to increase the transparency of zakat management. The indicator that reflects professionalism is the ability to make accountability reports in accordance with modern accounting principles 
b. Professionalism has a positive and significant effect on financial performance. This shows that better professionalism in the Amil Zakat Institute will be able to improve financial performance. The indicator that most reflects financial performance is the measurement of economic (ECON1) with the number of distributions of sabilillah fii rights as recipients of zakat.

c. Transparency of zakat management has a positive and significant effect on financial performance. This shows that better transparency of zakat management by the Amil Zakat Institution will be able to improve financial performance. The dimension that most reflects the transparency of zakat management is information on fund management (IFUND2), with indicators providing data/information at zakat agency offices.

\subsection{Recommendation}

a. Based on the results of the study with regard to improving the financial performance of the Amil Zakat Institution, practitioners should focus on improving the transparency variable in the management of zakat, namely on the information management dimension of the Amil Zakat Institution funds. This involves an increase in the provision of data/information periodically to zakat givers and providing data/information in zakat agency offices.

b. The professionalism of amil zakat is the key to the success of zakat management, so regulators need to issue regulations demanding increased competence. All training must be certified, with the same standards for all assessments, which will help amil zakat achieve optimal skills.

c. This study uses the tarnspatial zakat variable as a moderation variable, so further research will be able to produce different findings needed using other variables.

\section{REFERENCES}

Adnan, M.A. (2017). The Need of Establishment of Professional Amil Zakat to Enhance the Future Zakat Development. International Journal of Zakat, 2(1), 7179.

Akbar, N. (2009). Analisis Efisiensi Organisasi Pengelola Zakat Nasional Dengan Pendekatan Data Envelopment Analysis. Tazkia Islamic Finance \& Business Review, 4(2), 22-30.

Ascarya \& Rahmawati, S. (2018). Analysis of the Determinants of Micro Enterprises Graduation. Journal of Islamic Economics, Banking and Finance (JIEBF), 14(1), 12 $-63$.

Asfarina, M., Ascarya, \& Beik, I.S. (2019). Classical and Contemporary Fiqh Approaches to Re-Estimating the Zakat Potential in Indonesia. Journal of Islamic Monetary Economics and Finance, 5(2), 387-418.

Bakar, N.B.A. \& Rahman, A.R.A. (2007). A Comparative Study of Zakah and Modern Taxation. J.KAU: Islamic Economics, 20(1), 25-40.

Bastiar, Y. \& Bahri, E.S. (2019). Model Pengkuran Kinerja Lembaga Zakat di Indonesia. Jurnal Zakat dan Wakaf, 6(1), 43-64. 
Bentler, P.M., \& Chou, C.P. (1987). Practical Issues in Structural Modeling. Sociological Methods \& Research, 16(1), 78-117.

Cahyasumirat, G. (2006). Pengaruh Profesionalisme dan Komitmen Organisasi

Terhadap Kinerja Internal Auditor, Dengan Kepuasan Kerja Sebagai Variabel Intervening (Studi Empiris Pada Internal Auditor PT. Bank ABC). Semarang: Universitas Diponegoro. Tesis.

Devi, A.R. (2018). Pengaruh Profesionalisme, Job Stress, dan Perilaku Etis Terhadap Kinerja Karyawan Pada Badan Amil Zakat Nasional (BAZNAS) di Jawa Timur. Surayaba: UIN Sunan Ampel. core.ac.uk, 1-23

Endahwati, Y.D. (2014). Akuntabilitas Pengelolaan Zakat, Infaq, dan Shadaqah (ZIS). Jurnal Ilmiah Akuntansi dan Humanika, JINAH, 4(1), 1356-1389.

Firdaus, M., Beik, I.S., Irawan, T., \& Juanda, B. (2012). Economic Estimation and Determinations of Zakat Potential in Indonesia. IRTI Working Paper Series, WP 1433-07, Kingdom of Saudi Arabia.

Firmansyah, I \& Devi, A. ( 2017). The Implementation Strategies of Good Corporate Governance for Zakat Institutions in Indonesia. International Journal of Zakat, 2(2), 85-97.

Fitzgerald, L., Johnston, R., Brignall, T.J., Silvestro, R., \& Voss, C. (1991). Performance Measurement in Service Businesses. London: CIMA.

Habib, A. (2008). Zakah, Microeconimic Policies and Poverty Alleviation: Lessons From Simulations in Bangladesh. Journal of Islamic, Banking and Finance, 4(2), 81-105.

Hair Jr, J.F., Anderson, R.E., Tatham, R.L, \& Black, W.C. (1998). Multivariate Data Analysis 5th Edition. Upper Saddle River, USA: Prentice Hall.

Hair, J.F., Black, W.C., Babin, B.J., \& Anderson, R.E. (2006). Multivariate data analysis 6th Edition. New York: Pearson Prentice Hall.

Hasan, M. (2011). Manajemen Zakat Model Pengelolaan yang Efektif. Yogyakarta: Idea Press.

Kaen, F.R. (2003). A Blueprint for Corporate Governance. New York: American Management Association.

Kurniawanda, A.M. (2013). Pengaruh Profesionalisme Auditor dan Etika Profesi Terhadap Pertimbangan Tingkat Materialitas. E-Jurnal Binar Akuntansi, 2(1), 27-37.

Laela, S. F. (2010). Analisis Faktor-Faktor yang Mempengaruhi Kinerja Organisasi Pengelola Zakat. Islamic Finance and Business Review, 5(2), 126-146.

Lee, S.Y. (2007). Structural Equation Modeling A Bayesian Approach. West Sussex: John Wiley and Sons, Ltd.

Maister, D.H. (1997). Managing the Professionalism Service Firm. Free Press.

Mashudi. (2012). Evaluasi Pengelolaan Zakat di Indonesia. Retrieved from https:// infoislamicbanking.wordpress.com/2012/01/23/evaluasi-pengelolaan-zakatdi-indonesia/.

Muda, M., Marzuki, A., \& Shaharuddin, A. (2006). Factors Influencing Individual Participation in Zakat Contribution: Exploratory Investigation. Paper submitted for presentation at the Seminar for Islamic Banking and Finance 2006 (iBAF2006), 29 - 30 August 2006, Kuala Lumpur.

Muhtada, D. (2007). Rekonseptualisasi Zakat Untuk Keadilan. Koordinator Lembaga Amil Zakat MIIAS (Masyarakat Islam Australia Selatan). 
Mulaik, S.A. (1972). The Foundations of Factor Analysis. New York: McGraw Hilal Book Company.

Noor, M. Abd H., Rozman, Hj M. Y., \& Ahmad Che Y. (2007). Pengembangan Sistem Akuntansi Zakat dengan Teknik Fund Accounting. Konferensi zakat se Asia Tenggara. Padang Sumatera Barat.

Nurhayati, N. \& Rahmi, S.D. (2016). Pengaruh Transparansi dan Akuntabilitas Pelaporan Keuangan Terhadap Kinerja Keuangan Pada Lembaga Amil Zakat di Kota Bandung. Kajian Akuntansi, 17(1), 113-135.

PIRAC. (2012). Pola dan Kecenderungan Masyarakat dalam Berzakat (Hasil Survey Sebelas Kota di Indonesia). Jakarta: PIRAC.

Poister, T.H. (2003). Measuring Performance in Public and Nonprofit Organizations. San Francisco: John Wiley \& Sons, Inc.

Pusat Pungutan Zakat-Majlis Agama Islam Wilayah Persekutuan. (2009). Laporan Zakat 2008.

Rahman, A.R.A. (2007). Pre-requisites for Effective Integration of Zakah Into Mainstream Islamic Financial System in Malaysia. Islamic Economic Studies, $14(1 \& 2), 91-107$.

Rahman,. B. (2013). Manajemen Mutu Lembaga Pendidikan, Tenaga Kependidikan. Teori dan Praktik melejitkan produktivivitas. Yogyakarta: Graha Ilmu.

Revers, M. (2014). The Twitterization of News Making: Transparency and Journalistic Professionalism. Journal of Communication, 64(5), 806-826.

Sari, M.D., Bahari, Z. \& Hamat, Z. (2013). Review on Indonesian Zakah Management and Obstacles. Social Sciences, 2(2), 76-89.

Septiarini, D.F. (2011). Pengaruh Transparansi dan Akuntabilitas Terhadap Pengumpulan Dana Zakat, Infaq dan Shodaqoh Pada LAZ di Surabaya. Akrual, 2(2), 172-199.

Sularno. (2010). Pengelolaan Zakat Oleh Badan Amil Zakat Daerah Kabupaten / Kota Se Daerah Istimewa Yogyakarta. Jurnal Eknomi Islam La Riba, 4(1), 34-44.

Taha, R., Adam, F., Ali, N.N.M \& Ariff, A.M. (2017). Religiosity and Transparency In The Management of Zakat Institutions. Journal of Legal, Ethical and Regulatory Issues, 20(1), 23-30.

Trussel, J.M., \& Parsons, L.M. (2008). Financial Reporting Factors Affecting Donations to Charitable Organizations. Advances in Accounting, 23, 263-285.

Wahab, N.A., Zainol, Z \& Bakar, M.A. (2017). Towards Developing Service Quality Index for Zakat Institutions. Journal of Islamic Accounting and Business Research, 8(3), 326-333.

Wahab, N.A. \& Rahman, A.R.A. (2011). A Framework to Analyse Efficiency and Governance of Zakat Institutions. Journal of Islamic Accounting and Business Research, 2(1), 43-62.

Wahab, N.A \& Rahman, A.R.A. (2012). Efficiency of Zakat Institutions in Malaysia: An Application of Data Envelopment Analysis. Journal of Economic Cooperation and Development, 33(1), 95-112.

Wahid, H., Ahmad, S., \& Kader, R.A. (2009). Pengagihan Zakat Oleh Institusi Zakat di Malaysia: Mengapa Masyarakat Islam Tidak Berpuas Hati? Shariah Journal, 17(1), 89-112.

Wahyuni, I.N. (2016). The Efficiency of National Zakat Organizations Management Using Data Envelopment Analysis. Journal of Islamic Economics Lariba, 2(1), 1-10. 
Wise, R. (2001). Public Management Reform: Competing Drivers of Change. Public Administration Review, 62(5), 556-567.

Yuliafitri and Khoiriyah. (2016). Pengaruh Kepuasan Muzakki, Transparansi dan Akuntabilitas Pada Lembaga Amil Zakat Terhadap Loyalitas Muzakki (Studi Persepsi Pada Laz Rumah Zakat). Jurnal Ekonomi Islam, 7(2), 205-218.

Zainal, H., Bakar, A.A., \& Saad, R.Al J. (2016). Reputation, Satisfaction of Zakat Distribution, and Service Quality as Determinant of Stakeholder Trust in Zakat Institutions. International Journal of Economics and Financial Issues, 6(7), 72-76. 


\section{APPENDIX}

\section{QUESTIONNAIRE}

\section{INSTRUCTIONS}

1. Please check $(\checkmark)$ on each item of statement or question.

2. Please answers all questions.

3. Please return the completed questionnaire to the esignated contact person.

Note:

SS : Strongly Agree

$S \quad$ : Agree

RR : Doubtful

TS : Disagree

STS : Strongly Disagree

\begin{tabular}{|c|c|c|c|c|c|c|}
\hline No & Statement & STS & TS & RR & $\mathrm{S}$ & SS \\
\hline \multicolumn{7}{|c|}{$\begin{array}{c}\text { Competence } \\
\text { I, as Amil Zakat, should have: }\end{array}$} \\
\hline 01 & The ability to analyze Zakat objects & & & & & \\
\hline 02 & $\begin{array}{l}\text { The ability to make accountability reports in } \\
\text { accordance with modern accounting principles }\end{array}$ & & & & & \\
\hline \multicolumn{7}{|c|}{$\begin{array}{c}\text { Commitment } \\
\text { I, as Amil Zakat, should: }\end{array}$} \\
\hline 03 & Serve the payers of Zakat (Muzaki) well & & & & & \\
\hline 04 & Serve the recipients of Zakat (Mustahik) well & & & & & \\
\hline \multicolumn{7}{|c|}{$\begin{array}{c}\text { Partnership } \\
\text { I, as Amil Zakat, should: }\end{array}$} \\
\hline 05 & Have a special officer who explains about zakat & & & & & \\
\hline 06 & $\begin{array}{l}\text { Have special officers who collaborate with zakat } \\
\text { collection organizations }\end{array}$ & & & & & \\
\hline \multicolumn{7}{|c|}{$\begin{array}{c}\text { Transparency } \\
\text { I, as Amil Zakat, should: }\end{array}$} \\
\hline 01 & $\begin{array}{l}\text { Provide written information / data to the zakat payer } \\
\text { on time }\end{array}$ & & & & & \\
\hline 02 & Provide regular data / information to the zakat payer & & & & & \\
\hline 03 & Provide data / information at the zakat agency office & & & & & \\
\hline 04 & $\begin{array}{l}\text { Provide data / information according to policies set by } \\
\text { zakat institutions }\end{array}$ & & & & & \\
\hline
\end{tabular}


This page is intentionally left blank 